\title{
Physical activity as determinant of daily energy expenditure
}

Citation for published version (APA):

Westerterp, K. R. (2008). Physical activity as determinant of daily energy expenditure. Physiology \& Behavior, 93(4-5), 1039-43. https://doi.org/10.1016/j.physbeh.2008.01.021

Document status and date:

Published: 01/01/2008

DOI:

10.1016/j.physbeh.2008.01.021

Document Version:

Publisher's PDF, also known as Version of record

Document license:

Taverne

Please check the document version of this publication:

- A submitted manuscript is the version of the article upon submission and before peer-review. There can be important differences between the submitted version and the official published version of record.

People interested in the research are advised to contact the author for the final version of the publication, or visit the DOI to the publisher's website.

- The final author version and the galley proof are versions of the publication after peer review.

- The final published version features the final layout of the paper including the volume, issue and page numbers.

Link to publication

\footnotetext{
General rights rights.

- You may freely distribute the URL identifying the publication in the public portal. please follow below link for the End User Agreement:

www.umlib.nl/taverne-license

Take down policy

If you believe that this document breaches copyright please contact us at:

repository@maastrichtuniversity.nl

providing details and we will investigate your claim.
}

Copyright and moral rights for the publications made accessible in the public portal are retained by the authors and/or other copyright owners and it is a condition of accessing publications that users recognise and abide by the legal requirements associated with these

- Users may download and print one copy of any publication from the public portal for the purpose of private study or research.

- You may not further distribute the material or use it for any profit-making activity or commercial gain

If the publication is distributed under the terms of Article $25 \mathrm{fa}$ of the Dutch Copyright Act, indicated by the "Taverne" license above, 


\title{
Physical activity as determinant of daily energy expenditure
}

\author{
Klaas R. Westerterp* \\ Department of Human Biology, Maastricht University, PO Box 616, 6200 MD Maastricht, The Netherlands
}

Received 25 October 2007; received in revised form 16 January 2008; accepted 23 January 2008

\begin{abstract}
Inter-individual variation in energy expenditure is mainly a function of differences in body size and physical activity. Intra-individually, the energy expenditure associated with physical activity, i.e. muscular contractions to perform body postures and -movements, is the most variable component of total energy expenditure. Determinants of activity associated energy expenditure (AEE), as derived from observational and intervention studies are presented. Twin studies showed that most of the between subject variation in AEE is explained by genetic factors. AEE of subjects in the confined environment of a respiration chamber was on average halve the value as observed in the same subjects in free-living conditions with doubly labeled water. In young adults, non-training activity was not affected by exercise training. However, in elderly subjects, exercise training induced an equivalent compensatory decline in non-training activity. Similarly, AEE was reduced during energy restriction and in patients with chronic disease increasing resting energy expenditure. Studies with exercise training showed the reduction is difficult to overcome. (C) 2008 Elsevier Inc. All rights reserved.
\end{abstract}

Keywords: Activity associated energy expenditure; Energy intake; Age; Exercise training; Chronic disease

\section{Introduction}

The main determinants of daily energy expenditure of a subject are body size and physical activity. Activity associated energy expenditure, i.e. the energy expenditure associated with muscular contractions to perform body postures and -movements is the most variable component of total energy expenditure. Since the introduction of the doubly labeled water method for the measurement of total energy expenditure for human use, about 25 years ago [1], truly quantitative estimates are available of activity induced energy expenditure (AEE) in daily life. Additionally, accelerometers for movement registration are more and more used to objectively assess physical activity including the activity frequency, duration and intensity, and can be used at a larger scale than the more expensive doubly labeled water method [2].

Here, a review is presented on the determinants of AEE as derived from observational and intervention studies. In the confined conditions of a respiration chamber, AEE was shown to be

\footnotetext{
* Corresponding author. Tel.: +31 43 3881628; fax: +31 433670976 .
}

E-mail address: k.westerterp@hb.unimaas.nl. highly variable between subjects, which could be based on genetics [3]. In young adults, exercise training has been shown to affect total energy expenditure while non-training activity seems to be unchanged [4]. On the other hand energy restriction seems to reduce AEE as was already shown in the Minnesota experiment [5]. Similarly, AEE seems to be negatively affected by chronic disease, especially when resting energy expenditure is elevated [6]. Recently, AEE got a promise when it was suggested to be critical in a person's resistance to weight gain during overeating [7].

\section{Activity associated energy expenditure as a function of genes and environment}

Activity induced energy expenditure ranges between a minimum of $5 \%$ of total energy expenditure for somebody with a physical activity level (PAL), total energy expenditure expressed as a multiple of resting energy expenditure $(\mathrm{PAL}=$ TEE/REE), of 1.2 and $50 \%$ at the maximum PAL of 2.5 [8]. AEE of a subject with an average PAL of 1.75 is one-third of total energy expenditure. Surprisingly, AEE of subjects in the confined environment of a respiration chamber with a floor-space of 
7 to $8 \mathrm{~m}^{2}$ was on average halve the value as observed in the same subjects in free-living conditions with doubly labeled water $[3,9]$. These results are an indication for the major contribution of non-exercise activity to AEE as the chamber values mentioned above were for conditions where subjects were allowed to move around without access to exercise equipment like a treadmill, ergometer or stepping benches.

There was a wide inter-individual variation of AEE under the same confined conditions of a respiration chamber. After adjusting for differences in body size by expressing AEE per kg body mass, AEE ranged from a minimum of $0.015 \mathrm{MJ} / \mathrm{kg}$ to a maximum of $0.045 \mathrm{MJ} / \mathrm{kg}$, while the mean value of $0.026 \pm$ $0.006 \mathrm{MJ} / \mathrm{kg}$ for women was similar to the value of $0.024 \pm$ $0.006 \mathrm{MJ} / \mathrm{kg}$ observed for men. The chamber value was significantly related to the value in free-living conditions, correlation coefficients 0.50 to $0.53(p<0.01)$, which indicated a genetic component.

The relative contribution of genetic and environmental factors to the variation in AEE was tested in a twin design [10]. Physical activity was registered with a triaxial accelerometer for movement registration (Tracmor; Philips Research, Eindhoven, Netherlands) and AEE was measured simultaneously with doubly labelled water in monozygotic and same-sex dizygotic twin pairs. Genetic factors explained $72 \%$ of the variance in AEE and explained $78 \%$ of the variance in physical activity as measured with the accelerometer. Thus, genes determine for a large part whether a person is prone to engage in activities and how much energy is expended for these activities.

\section{Exercise training and activity associated energy expenditure}

Physical activity may be a self-stimulating process. People who raise their activity often report an increased feeling of well being. Exercise may cause the release of endorphins in the brain, as a result of which addiction to exercise may occur. Alternatively, exercise might reduce physiological arousal to the pre-training level and subsequently higher exercise levels are necessary to maintain the established feeling of well being. On the other hand, it might be questioned whether added exercise training is compensated for by a reduction of non-training activity during the rest of the day. Doubly labeled water studies showed that the physical activity level of younger subjects was modified with exercise training while exercise training had no effect in older people [2]. Here, four studies are reviewed where non-exercise activity was measured with the Tracmor in subjects before and during an exercise training program.

Meijer et al. [4] recruited 28-41 year subjects, 16 women and 16 men, to participate in a training program, which aimed at running a 1/2-marathon competition after 10 months. Respondents who were active in any sport like running, jogging or other recreational sports for more than one hour per week were excluded. The training was spread over four sessions per week and increased running time from $14 \pm 4 \mathrm{~min} /$ day after 8 weeks to $21 \pm 10 \mathrm{~min} /$ day after 20 weeks. Training induced a significant increase in total energy expenditure around $25 \%$. Accelerometer output (Tracmor- 0 ) was significantly higher after 8 weeks and after 20 weeks when compared with the baseline measurement
(Fig. 1). This increase was almost completely due to the extra running activity resulting from the training schedule. Thus, nontraining activity was not affected by the endurance training. Van Etten et al. [11] investigated the effect of a weight-training program on non-training activity in 18 men, age 23-41 year. None of the subjects had engaged in a regular exercise program for at least two years before the study. The subjects had two workout sessions a week on non-consecutive days for 18 weeks, inducing an average increase in total energy expenditure of approximately $10 \%$ after 8 weeks, with no further change after 18 weeks. non-training activity, as measured with Tracmor-1, did not change between baseline and 8 and 18 weeks training. Mean values were, respectively, $812 \pm 133,814 \pm 166$, and $852 \pm$ 199 kCounts/day.

Goran and Poehlman [12] did observe no change in total energy expenditure in healthy elderly persons, 56-78 year, in response to endurance training. It was concluded that the cost of the training program was offset by a compensatory decline in non-training activity. One explanation was that the level of exercise, increasing to $85 \%$ of $\mathrm{VO}_{2 \max }$, was too vigorous and thus fatigued the elderly participants during the remainder of the day. Meijer et al. $[13,14]$ investigated the effect of a 12-wk exercise-training program of moderate intensity on non-training activity in elderly humans. Subjects, 55-68 year, trained twice a week in a fitness club at intensity around $50 \%$ of heart rate reserve. The training program did not increase the total daily physical activity level as monitored with Tracmor-2 (Fig. 2). On training days, subjects showed a significant decrease in nontraining activity, which fully compensated for the training activity after 12 weeks participation. Although the training program decreased non-training activity, a significant increase in maximal oxygen uptake of approximately $8 \%$ was observed. In addition, 12 weeks of training significantly reduced heart rate during exercise at sub maximal intensity.

In conclusion, the effect of exercise training on non-training activity is age dependent. In young adults, exercise training induced increases in total energy expenditure up to $25 \%$ while

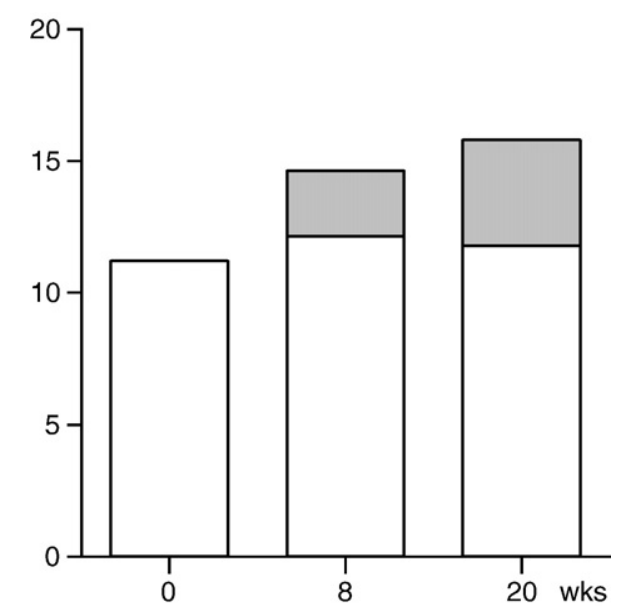

Fig. 1. Average accelerometer output (Tracmor-0, kCounts/d) of 32 subjects (16 women and 16 men, age 28-41 year) as measured over one week intervals before and after 8 and 20 weeks participation in a training program which aimed at running a 1/2 marathon competition after 10 months (adapted from [4]). 


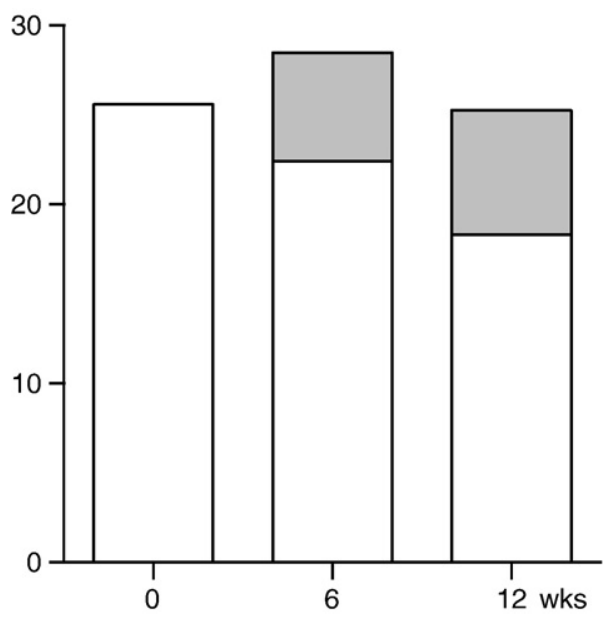

Fig. 2. Average accelerometer output (Tracmor-2, kCounts/d) of 37 subjects (19 women and 18 men, age 55-68 year) as measured over two weeks before and on training days after 6 and 12 weeks participation in a training program with two sessions per week at $50 \%$ of heart rate reserve (adapted from $[13,14]$ ).

non-training activity was not affected. In elderly subjects, exercise training had no effect on total energy expenditure through an equivalent compensatory decline in non-training activity.

\section{Under- and overeating and activity associated energy expenditure}

A classical study on the effect of semi-starvation in normalweight men is the so-called Minnesota Experiment [5]. The diet during a 12-week baseline weight maintenance period was 14.6 MJ/d. Subsequently; energy intake was reduced for 24 weeks to $6.6 \mathrm{MJ} / \mathrm{d}$. The subjects adjusted their energy expenditure to reach a situation of energy balance at $45 \%$ of ad libitum energy intake (Table 1). Of the mean total saving of $8.0 \mathrm{MJ} / \mathrm{d}$ the main part stemmed from reduced AEE. The AEE reduction could be split into a 'passive' component and an 'active' or real adaptation component, i.e. $40 \%$ of the reduction in AEE was due to a reduced body weight while $60 \%$ was a consequence of moving less. Velthuis-te Wierik [15] did a similar experiment, reducing intake under controlled dietary conditions by $33 \%$ for 10 weeks. Total energy expenditure decreased $20 \%$, from $14.3 \mathrm{MJ} / \mathrm{d}$ to $11.4 \mathrm{MJ} / \mathrm{d}$, i.e. subjects did not reach a new steady state within the observation interval. However, again more than $50 \%$ of the total saving of $2.9 \mathrm{MJ} / \mathrm{d}$ was a consequence of a reduction of AEE.

The reduction of AEE during energy restriction, as described above, is difficult to overcome. The addition of exercise training

Table 1

Energy saved by 24 weeks semi-starvation in the Minnesota Experiment [6]

\begin{tabular}{llll}
\hline & $\mathrm{MJ} / \mathrm{d}$ & $\%$ of total \\
\hline Basal metabolic rate & 2.6 & 32 & $\begin{array}{l}65 \% \text { for a decreased active-tissue mass } \\
35 \% \text { for a lowered tissue metabolism }\end{array}$ \\
$\begin{array}{l}\text { Diet induced energy } \\
\text { expenditure }\end{array}$ & 0.8 & 10 & \\
$\begin{array}{l}\text { Activity induced energy } \\
\text { expenditure }\end{array}$ & 4.7 & $58 \quad \begin{array}{l}40 \% \text { for a reduced body weight } \\
60 \% \text { for a reduced physical activity }\end{array}$ \\
\begin{tabular}{l} 
Total \\
\hline
\end{tabular} & 8.0 & 100 &
\end{tabular}

to an energy-restricted diet results in little further weight loss $[16,17]$. The additional exercise is compensated by a further reduction of non-training activity. Kempen et al. [18] provided women with a low-energy formula diet or an identical diet plus an exercise program. They observed a comparable decrease of total energy expenditure in the diet plus exercise and the dietonly group. Total energy expenditure dropped significantly, and to a similar extent, at both treatments suggesting no net effect of the exercise training on the activity associated energy expenditure.

Studies on the effect of overfeeding on energy expenditure were reviewed recently [19]. It is often suggested that humans differ in the susceptibility to weight gain in response to overfeeding. Seven years ago, AEE was presented as a new mechanism to explain differences in weight gain between subjects [7]. Activation of AEE could dissipate excess energy to preserve leanness and only failure to activate AEE resulted in ready weight gain. Unfortunately, accelerometer output as measured at baseline (2905 \pm 514 units/d) and during overfeeding (2963 \pm 537 units/d) was unchanged, and there is still little evidence for this form of adaptive thermogenesis from additional studies.

\section{Chronic disease and activity associated energy expenditure}

There is no significant difference in total energy expenditure between clinically stable patients with chronic obstructive pulmonary disease (CPOD) with a normal resting energy expenditure and those with an increased resting energy expenditure [6]. COPD patients with increased resting energy expenditure had a lower AEE than patients with normal resting energy expenditure (Fig. 3). Heart rate measurements, as an indirect indicator of the activity level, did not indicate a difference between both groups of patients. It might be that the energy cost of breathing in patients with COPD limits physical activity, especially in those with an increased resting energy expenditure.

Another limiting factor for physical activity, especially in patients with chronic disease like COPD, is the maintenance of

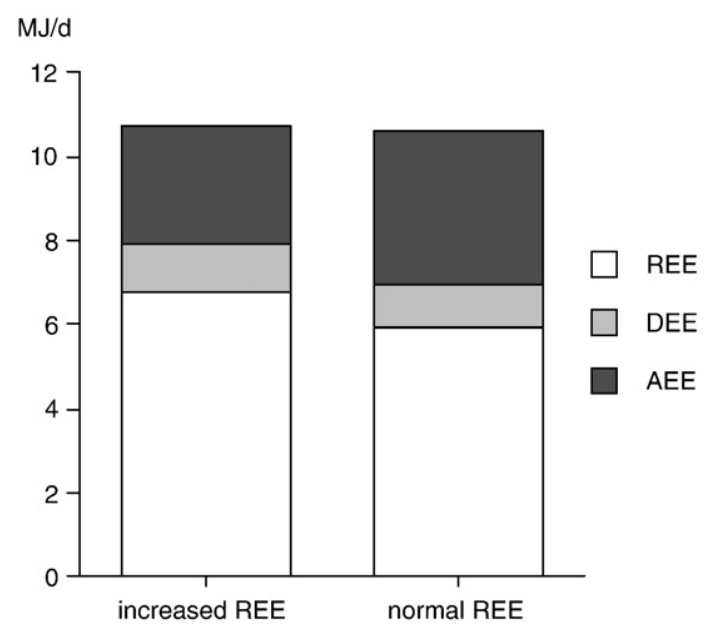

Fig. 3. Components of total energy expenditure: resting energy expenditure (REE); diet induced energy expenditure (DEE); and activity associated thermogenesis (AEE); in patients with chronic obstructive pulmonary disease with and without an increased REE (adapted from [6]). 
energy balance. Goris et al. [20] observed a significant relation between body mass change and physical activity level as assessed with Tracmor-2. COPD patients with a lower physical activity level were able to eat sufficient for their energy needs and remained in energy balance or even gained weight. A high physical activity level must be accompanied by a higher energy intake to maintain at least energy balance. This was apparently difficult for the already depleted COPD patients and they showed a further weight loss.

In conclusion, AEE is limited in chronic disease through an increased maintenance requirement and the 'competing' energy costs for the processing of food to prevent energy depletion.

\section{Discussion}

The variation in energy expenditure between subjects is a function of body size and physical activity, where AEE is an important contributor. Most of the variation in AEE is accounted for by genetic factors. Exercise training does not affect non-training activity as shown in intervention studies in young adults. However, elderly subjects compensate for the added exercise expenditure with a reduction of non-training activity. Similarly, AEE is reduced during energy restriction and in patients with chronic disease increasing resting energy expenditure. There is little evidence for a compensatory increase in AEE during overfeeding.

The relatively high contribution of genetic factors to whether a person is prone to engage in activities and how much energy is expended for these activities, as observed in adults, was not observed in a similar study in young children [21]. In twin pairs aged 4-10 year, familial resemblance in physical activity was predominantly explained by shared environment and not by genetic variability. However, behavior in childhood is plausibly governed more directly by others (eg, parents and teachers) than in adulthood, and this could restrict the expression of genetic effects as stated in the discussion of the results of this study [21]. The twins in the quoted study of Joosen et al. [10] were 1839 year of age, and members of twin pairs lived separately. Even then, a small common environmental factor in the genetic coefficient cannot be ruled out but certainly, genetic factors explained the largest part of the variation in body movement and the associated energy expenditure.

Non-exercise associated energy expenditure, generally is the largest component of activity induced energy expenditure. In all studies where the effect of exercise training on total energy expenditure in sedentary subjects was evaluated with doubly labeled water, non-exercise associated energy expenditure was still larger than exercise induced energy expenditure at the maximum training load [2]. Bingham et al. [22] gave subjects a nine-week supervised jogging training, which was gradually increased to $1 \mathrm{~h} / \mathrm{d}, 5 \mathrm{~d} / \mathrm{wk}$. In a control period before the training only light activities were allowed. Mean AEE in the control period was $2.56 \mathrm{MJ} / \mathrm{d}$ and at the end of the training $4.90 \mathrm{MJ} / \mathrm{d}$. In a study where sedentary subjects were trained over 40 weeks to run a halve-marathon, AEE was $3.36 \mathrm{MJ} / \mathrm{d}$ before the training started and 5.59 MJ/d at the end of the training [23]. In all other exercise-training studies, where the effect of exercise training was evaluated with doubly labeled water, exercise induced a smaller effect on energy expenditure.

Activity associated energy expenditure is a function of body weight and body movement. Interestingly, we described an increase in AEE in children and adolescents with increasing age, i.e. increasing body weight [24]. The increase in AEE could be attributed to an increase in weight, because there was no relation between AEE $/ \mathrm{kg}$ body weight and age. Another study also described a higher unadjusted AEE in adolescents than in children [25]. Here, after adjusting AEE for differences in body weight, AEE was significantly higher in children than in adolescents. Similarly, body movement as measured with an accelerometer was higher in children than in adolescents, confirming the procedure for adjusting AEE removes the confounding effect of body weight differences.

Accelerometers show that body movement is not necessarily equivalent to AEE. Obese adolescents had a similar AEE value to non-obese adolescents while body movement as measured with an accelerometer was significantly lower in the obese [26]. The increased costs of moving a larger body mass was reflected in a difference in body acceleration. The obese can perform less body movement even when there is no difference in AEE. They show less accumulated time in physical activity and thus are often blamed to be lazy.

Age is another determinant of AEE. Increasing age is associated with lower activity levels [27]. The effects of age are more pronounced for AEE than for the other components of total energy expenditure. Doubly labeled water studies show a decrease in the average proportion of total energy expenditure for AEE of about $35 \%$ at the age of 20 to $25 \%$ at the age of 90 . Comparing physical activity patterns of children, young adults and elderly, there is a decrease in the percent time spent in activities with high intensity and an increase in the time spent in activities with low intensity (Fig. 4) [28].

In conclusion, genes determine for the largest part whether a person is prone to engage in activities and how much energy is expended for these activities i.e. AEE. AEE decreases during energy restriction, during chronic disease, and with increasing

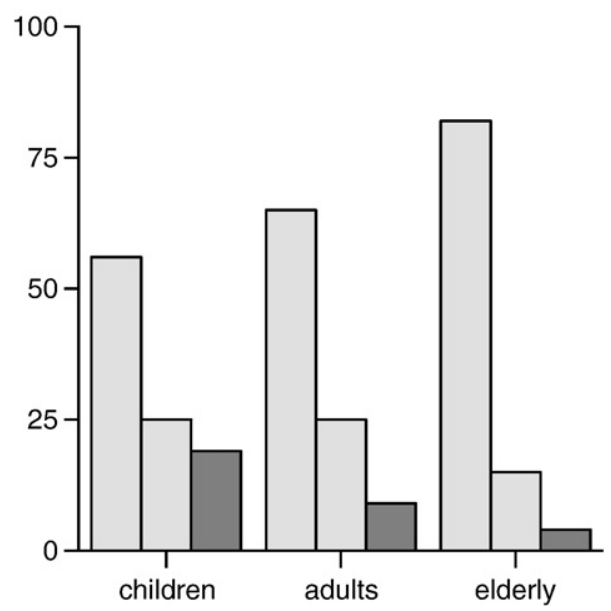

Fig. 4. Daily percentage of time spent on activities of low, moderate and high intensity in 5-12 year children, 20-35 year adults, and 55-68 year elderly (adapted from [28]). 
age. Then, it is difficult to overcome the decrease in AEE with exercise training.

\section{References}

[1] Schoeller DA, van Santen E. Measurement of energy expenditure in humans by doubly labeled water method. J Appl Physiol 1982;53:955-9.

[2] Westerterp KR, Plasqui G. Physical activity and human energy expenditure. Curr Opin Clin Nutr Metab Care 2004;7:607-13.

[3] Snitker S, Tataranni PA, Ravussin E. Spontaneous physical activity in a respiration chamber is correlated to habitual physical activity. Int J Obes 2001;25:1481-6.

[4] Meijer GAL, Janssen GME, Westerterp KR, Verhoeven F, Saris WHM, Ten Hoor F. The effect of a 5-month endurance-training program on physical activity: evidence for a sex-difference in the metabolic response to exercise. Eur J Appl Physiol 1991;62:11-7.

[5] Taylor HL, Keys A. Adaptation to caloric restriction. Science 1950;112: 2904.

[6] Baarends EM, Schols AMWJ, Westerterp KR, Wouters EFM. Total daily energy expenditure relative to resting energy expenditure in clinically stable patients with COPD. Thorax 1997;52:780-5.

[7] Levine JA, Eberhardt NL, Jensen MD. Role of nonexercise activity thermogenesis in resistance to fat gain in humans. Science 1999;283:212-4.

[8] Westerterp KR. Impacts of vigorous and non-vigorous activity on daily energy expenditure. Proc Nutr Soc 2003;62:645-50.

[9] Westerterp KR, Kester ADM. Physical activity in confined conditions as an indicator of free-living physical activity. Obes Res 2003;11:865-8.

[10] Joosen AMCP, Gielen M, Vlietinck R, Westerterp KR. Genetic analysis of physical activity in twins. Am J Clin Nutr 2005;82:1253-9.

[11] Van Etten LMLA, Westerterp KR, Verstappen FTJ, Boon BJB, Saris WHM. Effect of an 18-wk weight-training program on energy expenditure and physical activity. J Appl Physiol 1997;82:298-304.

[12] Goran MI, Poehlman ET. Endurance training does not enhance total energy expenditure in healthy elderly persons. Am J Physiol 1992;263:E950-7.

[13] Meijer EP, Westerterp KR, Verstappen FTJ. Effect of exercise training on total daily physical activity in elderly humans. Eur J Appl Physiol 1999;80:16-21.

[14] Meijer EP, Westerterp KR, Verstappen FTJ. The effect of exercise training on daily physical activity and substrate utilization in the elderly. Int J Sports Med 2000;21:499-504.
[15] Velthuis-te Wierik EJM, Westerterp KR, Van den Berg H. Impact of a moderately energy-restricted diet on energy metabolism and body composition in non-obese men. Int J Obes 1995;19:318-24.

[16] Garrow JS, Summerbell CD. Meta-analysis: effect of exercise, with or without dieting, on body composition of overweight subjects. Eur J Clin Nutr 1995;49:1-10.

[17] Ballor DL, Poehlman ET. A meta-analysis of the effects of exercise and/or dietary restriction on resting metabolic rate. Eur J Appl Physiol 1995;71: $535-42$.

[18] Kempen KPG, Saris WHM, Westerterp KR. Energy balance during 8 weeks energy-restrictive diet with and without exercise in obese females. Am J Clin Nutr 1995;62:722-9.

[19] Westerterp KR. Perception, passive overfeeding and energy metabolism. Physiol Behav 2006;89:62-5.

[20] Goris AHC, Vermeeren MAP, Wouters EFM, Schols AMWJ, Westerterp KR. Energy balance in depleted ambulatory patients with chronic obstructive pulmonary disease; the effect of physical activity and oral nutritional supplementation. Br J Nutr 2003;89:725-9.

[21] Franks PW, Ravussin E, Hanson RL, Harper IT, Allison DB, Knowler WC, et al. Habitual physical activity in children: the role of genes and the environment. Am J Clin Nutr 2005;82:901-8.

[22] Bingham SA, Goldberg GR, Coward WA, Prentice AM, Cummings JH. The effect of exercise and improved physical fitness on basal metabolic rate. Br J Nutr 1989;61:155-73.

[23] Westerterp KR, Meijer GAL, Janssen EME, Saris WHM, Ten Hoor F. Long-term effect of physical activity on energy balance and body composition. Br J Nutr 1992;668:21-30.

[24] Hoos MB, Westerterp KR, Kester ADM, Gerver WJ. Physical activity levels in children and adolescents. Int J Obes 2003;27:605-9.

[25] Ekelund U, Yngve A, Brage S, Westerterp K. Body movement and physical activity energy expenditure in children and adolescents: how to adjust for differences in body size and age. Am J Clin Nutr 2004;79: $851-6$.

[26] Ekelund U, Aman J, Yngve A, Renman C, Westerterp K, Sjöström M. Physical activity but not energy expenditure is reduced in obese adolescents: a case-control study. Am J Clin Nutr 2002;76:935-41.

[27] Westerterp KR, Meijer EP. Physical activity and parameters of aging: a physiological perspective. J Gerontol 2001;56A:7-12.

[28] Hoos MB, Kuipers H, Gerver WJM, Westerterp KR. Physical activity pattern of children assessed by triaxial accelerometry. Eur J Clin Nutr 2004;58: $1425-8$. 